\title{
Deriving the Properties of Structural Focus
}

\author{
Katalin É. Kiss \\ Research Institute for Linguistics \\ of the Hungarian Academy of Sciences
}

\section{Goal}

This paper proposes a theory of structural focus derived via focus movement which can account for all the focus-related facts attested in Hungarian, among them facts which other current theories cannot explain. It will claim that focus movement serves the purpose of creating a predicate-subject structure, in which the focus-moved constituent functions as a specificational predicate. The properties of both the focus and the background follow from the independently established properties of specificational predication constructions.

Section 2 of the paper briefly introduces two recent theories of focus movement: the 'movement for stress' theory of Szendröi (2003), and the 'movement for the checking of the exhaustive identification feature' theory of Horvath (2005), pointing out the problems which they cannot handle. Section 3 presents the proposal argued for. Section 4 demonstrates how the problems observed in section 2 receive a natural solution in the proposed framework. Section 5 discusses a further consequence of the proposed theory, involving the definiteness effect attested in presentational constructions.

\section{Some current theories of structural focus}

\subsection{Structural focus as a phonological phenomenon}

Szendröi's (2003) influential theory of structural focus aims to provide a unified analysis of English-type prosodic focus and Hungarian-type structural focus: both are claimed to be motivated by the stress-focus correspondence principle (Reinhart 1995, and Zubizarreta 1998), according to which

(1) The focus of a clause is a(ny) constituent containing the main stress of the intonational phrase, as determined by the stress rule.

Whereas in an English-type language the stress-focus correspondence is usually attained by stress shift, in a Hungarian type language it is claimed to be achieved by the movement of focus into the position of main stress, at the left edge of the verbal projection. (Szendröi analyzes the Hungarian sentence as a VP. Topic constituents are claimed to be extrametrical adjuncts, which are skipped by the stress rule.) The V 
movement accompanying Hungarian focus movement serves the purpose of establishing a functional projection the specifier of which provides a landing site for focus movement. Szendröi's 'movement for stress' theory of focusing raises several problems, namely:

(i) The structural focus in Hungarian does not necessarily bear main stress. If it is preceded by a universal quantifier (preposed to the left edge of the VP via overt Qraising), or certain types of adverbs, it can lack primary stress - as pointed out by Horvath (2005). In the following examples, the initial quantifier and adverb bear primary stresses, whereas the focus (spelled in capital letters) can be unstressed:

(2) a. 'Mindenkit [FocP JÁNOS hívott meg] everybody-ACC John invited PRT

'JOHN invited everybody. [For everybody, it was John who invited him.]'

b. 'Valóban [FocP JÁNOS késett el] indeed John was.late PRT

'Indeed it was John who was late.'

The focus is unstressed if it is given; e.g. (2b) would be felicitious in a context of the following type:

(3) a. Azt gyanítom, hogy [FocP JÁNOS késett el].

'I suspect that it was John who was late.'

b. 'Valóban [FocP JÁNOS késett el]

'Indeed it was John who was late.'

The intuition is that (3b) involves a second occurrence prosodic focus, with the first focus given, hence destressed - however, Szendői does not give any hint regarding how such an analysis could be executed in the framework outlined by her.

(ii) A more severe problem is that the uniform treatment of the English-type prosodic focus and the Hungarian-type structural focus hides their interpretational difference. It remains unaccounted for why structural focus - and only structural focus - has exhaustive interpretation; why (2a), unlike its English counterpart, is true if and only if everybody was invited only by John.

The exhaustivity of structural focus was first demonstrated by Szabolcsi (1981), on the basis of solid evidence often quoted in the literature ever since. ${ }^{1}$ Here let me only present two little known arguments.

According to Horn (1972), Levinson (2000), Kadmon (2001), and others, the basic meaning of a numerical modifier $n$ in natural language is 'at least $n$ '. Indeed, this is the meaning a Hungarian numerical modifier is associated with whether the modified expression is in postverbal argument position (4a) or in pre-focus topic position (4b). (Pragmatic factors can impose an upper limit on $n$-however, the upper limit is always a mere implicature which can be easily cancelled.) In the preverbal

\footnotetext{
${ }^{1}$ See also É. Kiss (1998; to appear), and Horvath $(2005,2006)$. For a somewhat different view, treating the exhaustivity of focus as an implicature, see Wedgwood (2005).
} 
focus position, however, the numeral $n$ can only mean 'exactly $n$ ' (4c), no matter what the pragmatic conditions are - which is derived from the [+exhaustive] feature of focus, i.e., the exclusion of all alternatives but the one denoted by the focused constituent in É. Kiss (to appear).

(4) a. János [PredP meg keres egy milliót havonta] John PRT earns one million-ACC monthly 'John earns a/one million a month.' (one million or more)

b. [TopP Egy milliót [PredP meg keres János havonta]] 'A/one million, John earns a month.' (one million or more)

c. János [FocP EGY MILLIÓT keres meg havonta] 'It is one million that John earns a month.' (exactly one million)

As shown by Szabolcsi (1981), $h a$ 'if' clauses are also interpreted differently in and out of focus. Conditionals, like other types of embedded clauses in Hungarian, have a pronominal head. When focused, the embedded clause is obligatorily extraposed, leaving only the pronominal head in the focus position of the matrix clause $(5 \mathrm{c})$. Whereas a $h a$-clause functions as a simple conditional both in postverbal position and in topic position, it is a biconditional (an if and only if clause) in focus position, which is again derived from the exhaustivity of focus by Szabolcsi (1981).

(5) a. Fel-hívlak [(akkor $)$ [ha János megérkezett $\left.]_{\mathrm{i}}\right]$ up call-I-you then if John arrived 'I will call you if John has arrived.'

b. [(Akkor $\left.{ }_{i}\right)$ [ha János megérkezett $\left.]_{i}\right]$, fel-hívlak. 'I will call you if John has arrived.'

c. [FocP $\mathrm{AKKOR}_{\mathrm{i}}$ hívlak fel, [ha János megérkezett $\left.]_{i}\right]$ 'I call you if and only if John has arrived.'

If focusing is merely movement for stress, as claimed by Szendröi (2003), the interpretational differences between $(4 a, b)$ and $(4 c)$, and between $(5 a, b)$ and $(5 c)$ cannot be predicted.

(iii) Szendröi's theory cannot handle the acceptibility difference between (6b) and (6c). Both sentences intend to answer the question What happened?, i.e., both are all-new sentences. In the English equivalents, the object bears primary stress in both cases. If focusing is movement for stress, the object should be focusable in both sentences. In (6c), however, the focus-movement of the object is unacceptable. 
(6) a. Mi történt? 'What happened?'

b. McCAINT választották elnökjelöltnek a republikánusok az USÁ-ban. McCain-ACC elected candidate the republicans the USA-in

'Republicans elected McCain presidential candidate in the USA.'

c.\%BENAZIR BHUTTÓT gyilkolták meg a fanatikusok Pakisztánban.

Benazir Bhutto-ACC murdered PRT the fanatics in Pakistan

'Fanatics murdered Benazir Bhutto in Pakistan.'

This example is also problematic for the focus theory of Fanselow (2006), according to whom focus movement is nothing but the movement of an accented constituent, and the focus position is not associated with any special semantic or pragmatic function.

(iv) According to Szendröi (2003: 37) the focus of an answer is the constituent that is questioned. In question-answer pairs like that in (7), however, it is the other way round: it is the familiar, non-questioned constituent of the question that has to undergo focus movement in the answer - contrary to prediction:

(7) a. Ki volt Fleming?/Mit tudsz Flemingről? 'Who was Fleming?/What do you know about Fleming?'

b. Ö/FLEMING fedezte fel a penicillint. he/Fleming discovered PRT the penicillin 'It was him/it was Fleming who discovered penicillin.'

A proper theory of structural focus should also account for examples of this type.

\subsection{Structural focus as a constituent with an exhaustive identification operator}

In reaction to Szendröi's theory of focus, Horvath $(2005,2006)$ has developed an alternative theory intended to account for the exhaustivity of the Hungarian focus, while maintaining the unified treatment of English and Hungarian focus. She claims that structural focus is an XP with an invisible Exhaustive Identification operator (EIOp) in its specifier, attracted to the specifier of an Exhaustive Identification Phrase in order to check the Exhaustive Identification features of its head. The EIOp requires association with focus.

This theory only eliminates problem (ii) of the stress-driven theory of focus movement, and also raises new problems, among them:

(v) The theory - correctly - acknowledges the structural difference between sentences of type (8a) and those of type (9a), which becomes transparent under negation. In (8a), orvos 'doctor' occupies the specifier of EIP, where it precedes the verb also when negated: 
(8) a. Az apám [EIP ORVOS [volt]]. my father doctor was

'My father was a doctor.'

b. Az apám [NegP nem [EIP ORVOS [volt]]

my father not doctor was

'My father wasn't a doctor.'

In (9a), on the other hand, jó orvos 'good doctor' occupies the position of the verbal modifier (identified here as Spec,PredP), where it is preceded by the V, undergoing head movement, in negative sentences:

(9) a. Az apám [Predp jó orvos [Pred' volt]].

my father good doctor was

'My father was a good doctor.'

b. Az apám [NegP nem [volt [PredPjó orvos]]]

my father not was good doctor

'My father wasn't a good doctor.'

What Horvath's theory leaves unexplained is why orvos - as opposed to jó orvos - is to be focused in the unmarked case.

(vi) In the framework of the EIOp theory, the object in (10) is associated with an EI operator, the effect of which is cancelled by the expression többek között 'among others'. It seems uneconomical to introduce an operator and immediately neutralize it.

(10) Többek között JÁNOST hívtam meg. / JÁNOST hívtam meg többek között. among others John-acc invited-I PRT

'It was John, among others, that I invited.'

(vii) Hungarians tend to move to focus position also constituents whose interpretation is inherently exhaustive.

(11) Andrásnak [FocP DECEMBER 13-ÁN van a születésnapja] Andrew December 13th-on has the birthday-his

'It is on December 13th that Andrew has his birthday.'

December 13th exhausts the set of days of Andrew's birth. It seems redundant, hence uneconomical, to mark its exhaustivity also with an EI operator.

(viii) It does not follow from the theory why universal quantifiers cannot be focussed:

(12)*MINDEN FIÚT hívtam meg. every boy-ACC invited-I PRT

'I invited everybody.'

(ix) It is unexplained why a bare nominal, ungrammatical in argument position, becomes perfectly acceptable if focussed: 

(13)
a. *Évát fel-kérte szöke fiú.
Eve-ACC PRT asked[for a dance] blond boy-NOM
b. Évát SZŐKE FIÚ kérte fel.
'It was a blond boy that asked Eve for a dance.'

\section{The proposal: focus as a specificational predicate}

The present proposal adopts Higgins's (1973) analysis of the English pseudo-cleft focus, and Huber's (2000) analysis of the Swedish and German cleft focus to Hungarian structural focus. ${ }^{2}$ In the theory developed by Higgins and Huber, pseudocleft and cleft sentences instantiate a type of predication structure called specificational predication. The wh-clause represents the subject of predication, and the (pseudo-)cleft constituent, identified as the focus, represents the predicate. In specificational predication constructions, neither the subject, nor the predicate is claimed to be referential. ${ }^{3}$ In the formulation of Huber (2000), the subject determines a set, and the predicate referentially identifies it, by listing its members. The predicate, i.e., the (pseudo-)cleft focus, is exhaustive because the referential identification of a set consists in the exhaustive listing of its members. The subject is associated with an existential presupposition because only an existing set can be referentially identified.

I claim that focus movement in Hungarian - and presumably in other languages, as well - serves the purpose of establishing a predicate-subject articulation to be interpreted as a specificational predication construction. The focus-moved constituent functions as the specificational predicate, and the post-focus sentence part (the background) functions as the subject of predication. ${ }^{4}$ The subject of predication, an open sentence, determines a set, which the focus identifies referentially. The referential identification of the set determined by the background is predicted to entail the exhaustive listing of its members. Furthermore, the background is predicted to be associated with an existential presupposition.

\footnotetext{
${ }^{2}$ For previous formulations of this proposal, see É. Kiss (2006a,b). For an extension of Higgins' (1973) analysis to English truncated clefts, see Mikkelsen (2004).

${ }^{3}$ Mikkelsen (2004) argues that the predicate of a specificational construction is, nevertheless, more referential than its subject.

${ }^{4}$ Although in subsequent stages of the derivation, Q-raising and topicalization can remove certain constituents of the post-focus unit (the subject of predication), they remain represented by their copies in postverbal position.
} 


\section{The facts explained}

From the proposed analysis, all the properties of the Hungarian focus construction fall out, including the problematic facts enlisted under (i)-(ix) above.

Focus movement is triggered by the need of creating a predicate-subject structure, with the predicate and the subject mutually c-commanding (or $\mathrm{m}$ commanding) each other.

The fact that focus-movement goes together with $\mathrm{V}$-movement seems to be independently motivated, as focusless negated sentences and e.g. imperatives also involve V-movement. Apparently, a neutral predicate, with its preverbal position occupied by the secondary predicate: a verbal particle, a predicative NP or a predicative AdvP (see, e.g., (14)) cannot be further extended by an operator; it can merely be merged with Q-raised quantifiers, adverbials, and topics. The neutral predicate can only be combined with a further operator if it becomes $\mathrm{V}$-initial, i.e., if it undergoes V-movement (see, e.g., (15)). Thus V-movement signals a kind of typeshift: the predicate phrase becoming the argument of a higher predicate.

(14) PredP

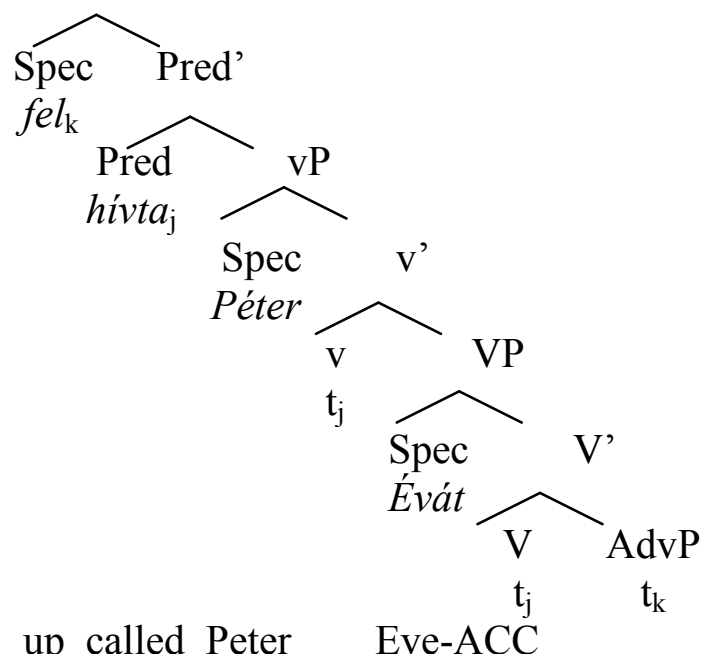

'Peter called up Eve.' 
(15) FocP

Peter not called up

This is how the proposed analysis accounts for problems (i)-(ix). Problem (i), illustrated by examples (1a,b), concerns the question why the structural focus of the Hungarian sentence does not always bear main stress. In the proposed framework, there is no direct relation between structural focus and stress. In Hungarian, Nuclear Stress is assigned to the leftmost constituent in a phrase. There is also a stressreduction rule which destresses given (anaphoric) constituents. If the filler of Spec,FocP is preceded by quantifiers and/or adverbials adjoined to FocP, they are also assigned Nuclear Stresses, as shown in (1a) and (1b). Any of the constituents marked as 'strong' by the Nuclear Stress Rule can also be destressed, if it is anaphorically given. This is what happens to the focus in both (1a) and (1b).

Problems (ii), (vi) and (vii), related to the exhaustivity of structural focus, are explained by the specificational predicate function of focus. Specification means the referential identification of a set by listing its members, hence it is understood to be exhaustive, as illustrated by examples (4) and (5). However, exhaustivity is not asserted in focus constructions; it is merely entailed. That is why focusing is not redundant even when exhaustivity appears to be neutralized right away by the overt expression többek között 'among others' (cf. (10)), and when it is also lexically entailed, as in (11). Sentences (10) and (11) are not formulated as specificational constructions in order to mark the exhaustivity of focus. (11) serves the purpose of

\footnotetext{
${ }^{5}$ The postverbal section of the Hungarian sentence, i.e., the vP in (14), and the PredP in (15), can be freely linearized. The optimal postverbal order is that observing Behaghel's (1932) Law of Growing Constituents - see É. Kiss (2008).
} 
identifying the day when Andrew has his birthday, whereas (10) serves the purpose of specifying the set of those I invited. This set is specified in part by an R-expression (János), in part by a kind of pronominal expression (többek (között) '(among) others').

Examples (6) and (8)-(9), illustrating problems (iii) and (v), show that specificational predication is licensed if the background is associated with an existential presupposition. ${ }^{6}$ Although both (6b) and (6c) are all new sentences answering the question What happened, in the case of (6b) it is part of the knowledge base of the speaker and the listener that there is someone that the Republicans will elect, or have already elected, presidential candidate in the USA. ${ }^{7}$ In the case of (6c), the focusbackground articulation is impossible because the background lacks an existential presupposition: When Benazir Bhutto was murdered, it was not shared knowledge that there was someone that fanatics would murder or had already murdered in Pakistan.

The minimal pair in (8) and (9) illustrate the same point. In the case of a grown-up person it is presumed that he has an occupation; when asking (8a) we are merely interested in the specification of this occupation. Thus (8a) amounts to asking 'is it true that the profession that your grandfather had is the profession doctor?' Being a good doctor, on the other hand, is not the specification of a generally held assumption.

Problem (iv) is also related to problems (iii) and (v). The question is why we have to focus Fleming/he in (7b), when Fleming/he represents the only given element in the sentence. Observe another question-answer pair illustrating the same point: ${ }^{8}$

(16) a. Who was Jack Ruby?

b. [FocP Ö [NNP lötte le Lee Harvey Oswaldot]]
he shot PRT Lee Harvey Oswald
'It was him who shot Lee Harvey Oswald.'

Both (7b) and (16b) are clear instances of specificational predication: their backgrounds determine a set associated with an existential presupposition (the set 'who invented penicillin', and the set 'who shot Lee Harvey Oswald', respectively), which the focus referentially identifies. It is not a requirement that the set to be specified must be given information, and the listing of its member(s) must be new; it can just as well be the other way round, as happens in (7) and (16).

The focus-background articulation of the answer is not licensed if the background is not associated with an existential presupposition; thus the discourse in

\footnotetext{
${ }^{6}$ According to Geurts and van der Sandt (2004), the background is associated with an existential presupposition in all types of focus constructions. They call the following rule 'the null hypothesis':

(i) The Background-Presupposition Rule

Whenever focusing gives rise to a background $\lambda x . \varphi(x)$, there is a presupposition to the effect that $\lambda x . \varphi(x)$ holds of some individual.

${ }^{7}$ Delin \& Oberlander (1995) make a similar claim about the subordinate clause of cleft sentences: they count as presuppositional also when they convey information that is expected to be known.

${ }^{8}$ The English equivalents of (7b) and (16b) are called comment-clause clefts by Delin and Oberlander (1995).
} 
(17) is unacceptable - unless there has already been discussion about a certain man who shot his wife.

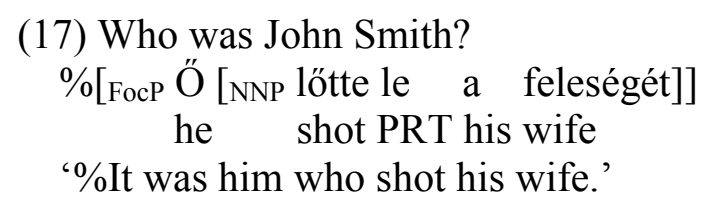

Problem (viii) was the question why a universal quantifier cannot be focussed. Giannakidou and Quer (1995) have shown that universal quantifiers cannot be used as predicate nominals, in other words, as nominal predicates. If the focus functions as a predicate, the impossibility of focussing a universal quantifier is predicted. ${ }^{9}$

Problem (ix), illustrated by example (13), also represents a consequence of the predicate status of focus. A bare NP, which cannot function as an argument, ${ }^{10}$ is grammatical as a predicate in Hungarian:

(18) a. Éva vőlegénye szőke fiú (volt).

Eve's fiancé blond boy (was)

'Eve's fiancé is/was a blond boy.'

b. A tettest szőke fiúnak hitték. the offender-ACC blond boy-DAT saw-they

'The offender was seen to be a blond boy.'

In (13b), the bare nominal subject is grammatical because the focus position it occupies is associated with a (specificational) predicate interpretation.

\footnotetext{
${ }^{9}$ Puskas 2000:342) claims that this does not hold in Hungarian, on the basis of examples like

(i) Emőke (volt) minden örömöm.

Emöke (was) all joy-my

'Emöke is/was all my joy.'

According to Surányi (2002), the constraint formulated by Giannakidou and Quer (1995 ) does not apply to all-type universal quantifiers. However, in Hungarian, every and all-type quantifiers do not seem to differ in the relevant respect (neither of them can be focussed). In my analysis, Emöke is the predicate nominal in (i), and minden örömem is the subject. If minden örömem were a predicate nominal, it ought to be able to precede the verb volt (occupying first Spec,PredP, and then Q-raised into a PredP-adjoined position). Furthermore, if Emöke were the subject, it ought to be able to undergo topicalization, i.e., to occupy an unstressed clause-initial position. Both of these moves are impossible:

(ii)*Emöke 'minden örömöm volt.

Emöke all joy-my was

'Emőke was all my joy.'

Cf.

(iii) Minden örömöm Emőke volt.

'All my joy was Emőke.'

${ }^{10}$ In fact, a semantically incorporated theme or goal argument, occupying Spec,PredP, the position of secondary predicates, can be represented by a bare nominal.
} 


\section{A further consequence of the proposal}

The proposed analysis is further supported by the fact that it has good consequences in other areas of grammar, as well. For example, it can explain a curious correlation between focusing and definiteness effect.

As is well-known from the literature (Szabolcsi 1986, É. Kiss 1995, Piñón 2006a,b, Peredy 2008, and the references therein), verbs of (coming into) being and creation require a non-specific theme. Compare:

(19) a. Született egy baba. was.born a baby 'A baby was born.'
b.*A baba született. the baby was.born 'The baby was born.'

b. *János minden autót szerzett. ${ }^{11}$ John every car obtained

Interestingly, the focusing of an adjunct, or the focusing of the agent neutralizes the 'definiteness effect', i.e., the non-specificity requirement on the theme; the focusing of the theme, on the other hand, has no such neutralizing effect:

(21) a. A baba TEGNAP született. the baby yesterday was.born 'The baby was born YESTERDAY.'

b.*A KISLÁNY született. the little.girl was.born 'THE LITTLE GIRL was born.

(22) a. Minden autót JÁNOS szerzett. every car-ACC JOHN obtained 'Every car was obtained by JOHN.'

b. János minden autót ILLEGÁLISAN szerzett. John every car illegally obtained 'John obtained the car from a relative of his.'

\footnotetext{
${ }^{11}$ Hungarian verbs of (coming into) being and creation also have particle verb counterparts, which denote the change of their theme, the existence of which is presupposed. These particle verbs, as opposed to their bare $\mathrm{V}$ equivalents, select a [+specific] theme:

(i)a. A gyerekek meg-születtek. the children PRT-were.born

'The children were born.'

b. *Gyerekek meg-születtek.

(ii)a. János meg-szerezte az autókat. John PRT obtained the cars

' John obtained the cars.'

b. *János meg-szerzett autókat.
} 
Szabolcsi (1986) derived the (in)definiteness effect illustrated in (19) and (20) from the meaning of the verbal predicates: they assert the (coming into) being of their theme argument; hence the existence of their theme cannot be presupposed; that is why they cannot be associated with a determiner eliciting a [+specific] reading. In (21) and (22), both the verb expressing coming into being and the theme whose coming into being it denotes constitute (part of) the background of a focus-barkground construction, in other words, (part of) the subject in a specificational predication structure. (More precisely, in (22) it is the variable bound by the Q-raised universal quantifier that represents the theme argument in the background/subject of predication.) Recall that the subject of a specificational predication construction is associated with an existential presupposition, i.e., the event of the theme's coming into being is presupposed in both cases; that is why also a [+specific] theme is licensed. However, if the theme is the focus/specificational predicate, no existential presupposition is assigned to it, hence the (in)definiteness effect is not neutralized.

\section{Conclusion}

The paper has proposed a theory of structural focus which analyzes focus movement as the establishment of a syntactic predicate-subject structure, expressing specificational predication in the sense of Higgins (1973) and Huber (2000). It is claimed that this analysis also accounts for properties of focus movement constructions that current alternative theories cannot explain. The subject of a specificational construction, an open sentence, determines a set, which the predicate (the focus-moved constituent) identifies referentially. The crucial properties of a specificational predication construction are the existential presupposition associated with the subject of predication (only an existing set can be referentially identified), and the exhaustivity of the focus (the referential identification of a set consists in the exhaustive listing of its members). Hence the [+exhaustive] feature of the focus is not asserted, but is always present as an entailment. The specificational predicate-subject of predication (in other words, the focus-background) articulation of the sentence does not correlate with either the new-given division of the information conveyed (the open sentence determining the set to be identified (i.e., the background) can also be new, and the listing of the members of the set (i.e., the focus) can also be given). There is no direct correlation between the focus-background articulation and the stress pattern of the sentence, either (e.g., a given focus can be destressed).

\section{References}

Behaghel, Otto. 1932. Deutsche Syntax IV. Heidelberg: Carl Winters.

Delin, Judy J. and Jon Oberlander. 1995. Syntactic constraints on discourse structure: The case of it-clefts. Linguistics 33. 
É. Kiss, Katalin. 1995. Definiteness effect revisited. In: István Kenesei (ed), Levels and Structures. Approaches to Hungarian Vol. 5, 65-88. Szeged: JATE.

É. Kiss, Katalin. 1998.Identificational Focus versus Information Focus. Language 74. $245-273$.

É. Kiss, Katalin. 2006a. Apparent or real? On the complementary distribution of identificational focus and the verbal particle. In: É. Kiss, Katalin (ed), Event Structure and the Left Periphery. Studies on Hungarian, 201-224. Dordrecht: Springer.

É. Kiss, Katalin. 2006b. Focussing as predication. In: Valeria Molnár and Susanne Winkler (eds), The Architecture of Focus, 169-193. Berlin: Mouton de Gruyter.

É. Kiss, Katalin. 2008. Free word order, (non-)configurationality, and phases. Linguistic Inquiry 39. 441-475.

É. Kiss, Katalin. To appear. Structural focus and exhaustivity. In: Caroline Féry and Malte Zimmermann (eds), Proceedings of the 2006 Potsdam Conference on Focus, Oxford University Press.

Fanselow, Gisbert. 2006. On pure syntax. In: P. Brandt and E. Fuss (eds), Form, Structure and Grammar. Berlin: Akademie Verlag.

Geurts, Bart and Sandt, Rob. 2004.Interpreting Focus. Theoretical Linguistics 30. 144.

Giannakidou, A. and J. Quer 1995. Two mechanisms for the licensing of negative indefinites. In: L. Gabriele, D. Hardison, and R. Westmoreland (eds.), Formal Linguistics Society of Mid-America (FLSM) 6, Indiana Linguistics Club, Bloomington, 103-114.

Higgins, Roger F. 1973. The Pseudo-cleft Construction in English. PhD diss., MIT.

Horn, Laurence R. 1972. On the semantic properties of logical operators in English. Ph.D. diss., UCLA.

Horvath, Julia. 2005. Is "Focus Movement" driven by stress? In: Christopher Piñón and Péter Siptár (eds), Approaches to Hungarian 9. Papers from the Düsseldorf Conference, 131-158. Budapest: Akadémiai Kiadó.

Horvath, Julia. 2006. Separating "Focus Movement" from Focus. In: V. S. S. Karimi et al. (eds.), Clever and Right: A Festschrift for Joe Emonds. Berlin: Mouton de Gruyter. 
Huber, Stefan. 2000. Es-Clefts und det-Clefts. Almquist and Wiksell, Stockholm.

Kadmon, N. 2001. Formal Pragmatics. Oxford, Blackwell.

Levinson, S. C. 2001. Presumptive meanings. Cambridge, MA: MIT Press.

Mikkelsen, Line H. L. 2004. Specifying who: on the structure, meaning, and use of specificational copular clauses. PhD diss., University of California Santa Cruz.

Peredy, Márta. 2006. Obligatory adjuncts licensing definiteness effect constructions. In: Katalin É. Kiss (ed), Adverbs and Adverbial Adjuncts at the Interfaces Mouton de Gruyter, Berlin, to appear.

Piñón, Christopher. 2006a. Definiteness effect verbs. In: Katalin É. Kiss (ed), Event structure and the left periphery, 75-90. Springer, Dordrecht.

Piñón, Christopher. 2006b. Weak and strong accomplishments. In: Katalin É. Kiss (ed), Event structure and the left periphery, 91-106. Springer, Dordrecht.

Puskás, Genovéva. 2000. Word Order in Hungarian: The Syntax of A-bar Positions. Amsterdam: John Benjamins.

Reinhart, Tanya. 1995. Interface strategies. OTS Working Papers (TL-95-002).

Surányi, Balázs. 2002. Multiple Operator Movements in Hungarian. Utrecht: LOT.

Szabolcsi, Anna. 1981. The semantics of topic-focus articulation. In: J. Groenendijk et al. (eds), Formal Methods in the Study of Language, 513-540. Mathematisch Centrum, Amsterdam.

Szabolcsi, Anna. 1986. From the definiteness effect to lexical integrity. In: Werner Abraham and Sjaak de Meij (eds), Topic, Focus, and Configurationality, 321-348. John Benjamins, Amsterdam.

Szendröi, Kriszta. 2003. A stress-based approach to the syntax of Hungarian focus. The Linguistic Review 20. 37-78.

Wedgwood, Daniel. 2005. Shifting the Focus. From static structures to the dynamics of interpretation. Elsevier, Amsterdam.

Zubizarreta, Maria. 1998. Prosody, Focus, and word order. MIT Press, Cambridge, Mass. 
Katalin É. Kiss

Research Institute for Linguistics of the Hungarian Academy of Sciences

Budapest

Benczúr utca 33.

H-1068 Hungary

ekiss@nytud.hu 